\title{
CROSSING BOUNDARIES. THE TRANSFORMATIVE POTENTIAL OF INTERCULTURAL BIBLE READING IN SECULAR / POST-SECULAR CONTEXTS
}

\author{
Louis C. Jonker \\ Old and New Testament \\ University of Stellenbosch
}

\begin{abstract}
Intercultural biblical hermeneutics is a fairly recent development in biblical scholarship in general. It emphasises that biblical interpretation almost always takes place in contexts where an array of cultural values and beliefs determine the outcome of the interpretative process. Although this branch of biblical hermeneutics emerged from the need to reflect theoretically on how Christians from different socio-cultural and socio-economic contexts engage the biblical texts, and one another on account of those texts, this approach may also be widened to include the interpretation of the Bible in non-Christian contexts (including the contexts of other religions and secular contexts) or even to engage in discourse on the interpretation of authoritative texts of different traditions (such as the Qur'an in Islam, in addition to the Tenakh of Judaism, and the Old and New Testament of Christianity). In research on intercultural biblical hermeneutics, it has been noticed that intercultural interpretation holds enormous transformative potential. My paper will examine how this could be of use in engagements between religious, secular and post-secular contexts.
\end{abstract}

Keywords: Intercultural biblical hermeneutics; Secular and post-secular contexts; Biblical Interpretation; Teaching biblical studies; Transformative Bible interpretation

\section{Introduction}

The crossing of boundaries belongs to our time. Not only have many of us crossed several boundaries to get to this truly international conference in Lithuania (or even to teach here at Klaipeda), but the issues of immigration and cross-cultural influences also characterise the international dynamics in the first decades of the $21^{\text {st }}$ century. Many societies and cultural groupings, as well as individuals, are confronted by a diversity of cultures and values; and we all know that the encounter with the Other brings serious challenges to societies that have tended to be fairly homogeneous for centuries (See Casanova 20212:27-46). The exclusivist tide of political movements and sentiments that is sweeping over Western Europe (and even the US) stands as witness to the struggle to come to grips with the culturally-different Other. Among the challenges of our time are differences in languages, in cultural rituals, in values, and particularly in religion.

Although this situation is a very prominent characteristic of our own time (not only in Western Europe and the US but also on the African continent and elsewhere), it is not entirely new. The history of humankind has seen many phases of dissettlement and 
resettlement in different parts of the world. Wherever these processes of emigration and immigration took place, they went hand-in-hand with unsettling socio-historic and socioeconomic circumstances, and often with imperial aspirations. Even in the pre-Christian phases of history, we have seen many examples of this. Under the influence of the great Mesopotamian empires, and in conflict with the great Egyptian and Nubian empires in North-Africa, many conquests and exiles took place. The exiles of the Kingdom of Israel in $722 \mathrm{BCE}$ and of Judah in $587 \mathrm{BCE}$ are good examples.

Societies in transition as a result of the circumstances described above are often the very fertile soil within which different creative art forms (such as graphic and plastic art but also poetry and other kinds of literature) flourish. These art forms represent the inner processes of coming to grips with societal transition and identity negotiation. These situations also often prompt theological reflection in religious communities, which is then codified in scriptures that often become authoritative for coming generations. The greatest part of the Hebrew Bible (or Old Testament as it is known in Christianity) emerged from the post-exilic contexts of the Achaemenid Persian period and the subsequent Hellenistic era (see for example Schmidt 2014). Early Judaism, as it emerged from the post-exilic Persian period, reflected theologically on how it viewed its deity in new circumstances amidst a diversity of other cultures and religions that were tolerated during the Achaemenid period. The main question to be answered in this period was how faith in Yahweh, the deity of Judaism, should be structured in order to show its uniqueness in comparison to other religions and cults of the time, but also which identity the adherents of this religion had to accept to accentuate their uniqueness over-against other religions within the imperial context without endangering their relative safety and peaceful existence amidst the imperial rule (Jonker 2016; Giffone 2016:628). Books such as Chronicles and Ezra-Nehemiah are creative literary attempts to negotiate these big questions. How should one deal with the diversity of cultures and religions amidst the imperial existence (eds. Lipschits et. al. 2011)?

This introduction emphasises that the books of the Hebrew Bible (together with the New Testament, the founding documents of the Christian community coming to grips with their existence in the Roman empire) could potentially serve as valuable resources for our own $21^{\text {st }}$ century contexts. By analysing the inner-workings of these literary resources, one may expect to find strategies for coping in societies in transition, such as ours (see for example Cezula 2013).

There is, however, one important complication, namely that the Bible is often seen (by other religions but also in secular society) not as an instrument of reconciliation but rather as grounds for division and many of the conflicts that we have seen through the ages and also in our own time. The value of the Bible as a resource for societies in transition is contested. Great parts of the world experiencing transition at the moment are rather characterised as secular or post-secular societies. Western Europe is a good example of a post-secular society, while many contexts in Eastern Europe (who experienced the imperial influence of the former Soviet Union) could be considered to be secular. Could the Bible be offered to these societies as a resource to cope with cultural diversity and changing political dispensations?

Before trying to answer this pertinent question, I will first present some theoretical considerations that have an important bearing on our understanding of this issue. First (section 2), I will look at the distinction which is made between secular and post-secular 
societies, and their relation to culture. Secondly (section 3), I will explore the relationship between the Bible and culture. In the next section (section 4), I will present a recent development in biblical hermeneutics, namely intercultural biblical hermeneutics, before focusing on interculturality and transformation in a subsequent section (section 5). Only after these theoretical detours (in section 6), will I try to answer the question above, whether the Bible could potentially be a valuable resource in (post-)secular societies during times of cultural and religious transition. A conclusion will follow in the last section (section 7).

\section{Exploring the Relationship between (Post-)Secularism and Culture}

Since the famous publication by the Canadian philosopher Charles Taylor, A Secular Age, the debate on religion in society and secularity has become a prominent feature of reflections on our own time. Taylor (2007) started his book with two descriptions of secularity, what he calls Secularity 1 and Secularity 2. The first understanding indicates that our society has been fractured into two spheres, the private and the public. In former ages, reality was understood as being permeated by religion. However, in a secular age, religion has been pushed out of the public sphere into the private sphere. The Reformation's move to radically separate Church and State comes to mind here. The second understanding of secularity, according to Taylor (2007), is a turning away from God and a general decline in religiosity, both in practice and in belief. The radical decline in active membership in mainstream churches in big parts of the world serves as an example here. Taylor criticises these overly simplistic descriptions of secular society, as if it was merely a subtraction of religion from modern society under the influence of reason and scientific method. Taylor (2007) therefore offers a third way of understanding secularity. In the third way, he focuses on the radical changes in the conditions of belief that have taken place during the period of modernity. These shifts contributed to the present secular age, in which religious belief is no longer seen as a de facto position for understanding human aspirations towards fullness (as he calls it, or flourishing, in the parlance of contemporary reflections), but functions as one alternative amongst others (see also Casanova 2012).

Since Taylor's publication, what has been witnessed in these so-called "secular societies" is rather "the return of God", not the total disappearance of God and religion from public life as predicted in earlier descriptions of secularity. The tendencies of the early years of the $21^{\text {st }}$ Century went against all expectations. ${ }^{1}$ There are therefore more recent attempts to speak of our own time as a post-secular age. Very influential in this debate is the voice of Jürgen Habermas. Habermas (2008:19) does not deny that secularisation is characteristic of our time but rather states that "the weakness of the theory of secularization is due rather to rash inferences that betray an imprecise use of the concepts 'secularization' and 'modernization'”. He agrees with José Casanova that

[T] he loss of function and the trend toward individualization do not necessarily imply that religion loses influence and relevance either in the political arena and the culture of a society or in the personal conduct of life. Quite apart from their 
numerical weight, religious communities can obviously still claim a 'seat' in the life of societies that are largely secularized. Today, public consciousness in Europe can be described in terms of a 'post-secular society' to the extent that at present it still has to adjust itself to the continued existence of religious communities in an increasingly secularized environment. The revised reading of the secularization hypothesis relates less to its substance and more to the predictions concerning the future role of 'religion.' The description of modern societies as 'post-secular' refers to a change in consciousness. (Habermas 2008:19-20)

Habermas continues to attribute this change in consciousness to mainly three phenomena: (i) Global conflicts on account of religious strife ironically undermines the belief in some theories of secularisation that religion can (and will) be totally banned to the private spheres of life. Even in so-called secular societies, religion still imposes itself on public and political life. (ii) Religion is gaining influence also in national public spheres. According to Habermas (2008:20), "churches and religious organizations are increasingly assuming the role of 'communities of interpretation' in the public arena of secular societies. They can attain influence on public opinion and will formation by making relevant contributions to key issues, irrespective of whether their arguments are convincing or objectionable. Our pluralist societies constitute a responsive sounding board for such interventions because they are increasingly split on value conflicts requiring political regulation." (iii) Habermas indicates that the influx of other religious communities into Europe (mainly Islam, due to immigration) has ironically brought a greater awareness again among secular citizens of the valuable input that Christian communities can make. The pluralism of ways of life, which is typical of immigrant societies, emphasises the importance of the issue of tolerant coexistence. Habermas (2008:21) then continues to formulate the burning normative question of post-secular societies: "How should we see ourselves as members of a post-secular society and what must we reciprocally expect from one another in order to ensure that in firmly entrenched nation states, social relations remain civil despite the growth of a plurality of cultures and religious worldviews?"

Habermas emphasises that tolerance is thus needed in culturally-diverse societies, and this rests on a healthy balance between equal citizenship and cultural difference. However, he comments as follows:

'Tolerance' is of course, not only a question of enacting and applying laws; it must be practiced in everyday life. Tolerance means that the believers of one faith, of a different faith and non-believers must mutually concede to one another the right to those convictions, practices and ways of living that they themselves reject. This concession must be supported by a shared basis of mutual recognition from which repugnant dissonances can be overcome. ... [I]n the present context what is most important to me is the image of an inclusive civil society in which equal citizenship and cultural differences complement each other in the right way (Habermas 2008:23-24). 
Habermas indicates that our societies are often not characterised by this tolerance but rather by a Kulturkampf between, what he calls, 'radical multiculturalism' and 'militant secularism.' He summarises it as follows:

The party of the multiculturalists appeals to the protection of collective identities and accuses the other side of representing a 'fundamentalism of the Enlightenment,' whereas the secularists insist on the uncompromising inclusion of minorities in the existing political framework and accuse their opponents of a 'multiculturalist betrayal' of the core values of the Enlightenment. ... Thus the conflicting parties both pretend to fight for the same purpose, a liberal society that allows autonomous citizens to coexist in a civilized manner. And yet they are at loggerheads in a Kulturkampf that resurfaces at every new political occasion. Although it is clear that both aspects are interlinked, they argue bitterly over whether the preservation of cultural identity has priority over the enforcement of shared citizenship and vice versa (Habermas 2008:24-24).

Although Habermas' suggestion of complementary learning processes between secular and religious mentalities has been criticised in further discussions as too idealistic, I find his analysis of the present post-secular context convincing and useful for our further reflection on the role that the Bible can play in our age. En route to answering this question, I now turn to the role of culture in the Bible and in biblical interpretation.

\section{Culture and the Bible}

It is common knowledge that no literature emerges from a vacuum. There is always a real-life context that influences the themes and styles of literature. Whether or not this is acknowledged in contemporary interpretation processes (and I will deal with this aspect below) does not change the reality that literature emerges from real-life contexts. ${ }^{2}$ In earlier scholarship, the interest was primarily in the reconstruction of the past, that is, the Bible was seen as a valuable resource of history. However, as time went by and our methods became more sophisticated, the emphasis shifted to the history of the literature itself, as well as to the cultural environments within which they originated. Biblical texts were no longer seen as witnesses to the historical events of the past but rather as witnesses of how the cultural environments of their time contributed to the way in which these texts developed and grew over time. It became important to study the political culture, the religious culture, the economic culture, and the social culture of the time of origin of the biblical texts. Related fields; such as archaeology, iconography, numismatics, epigraphy, etc.; are therefore considered to be valuable resources to use when studying the material culture of the past in order to gain insight into the cultural dynamics that produced the biblical texts. ${ }^{3}$

However, as hinted at above, not all interpretations of the Bible take this important aspect into account. Gradually, since the 1960s, some reception-oriented approaches emerged in biblical studies. ${ }^{4}$ These approaches rightly emphasise that the cultural

See, e.g., the arguments in Jonker 2013.

See, e.g., the different discussions in Gertz et al. 2012.

For a description of these developments in biblical studies, see Louis C. Jonker and Douglas G. Lawrie 2005. 
environments within which texts are interpreted are also determinative for their understanding. As a result of this emphasis, a variety of hermeneutical approaches started developing: hermeneutics of liberation, hermeneutics of the poor, feminist hermeneutics, marxist hermeneutics, etc. These approaches emphasise that the cultural environment of interpretation, be it the political culture, economic culture, social culture, etc. should be studied to determine how it influences our understanding of the Bible.

Although both of these developments in biblical studies, namely interest in the cultural environments of origin/production of the texts and interest in the cultural environments of interpretation/reception of the texts, emphasise the role of culture, there is normally no mutuality between these approaches. They are often seen as oppositional positions - either the one is valued or the other, but not both (Jonker 2013). Unfortunately, the shift of interest to the reception side - although a valuable move in itself - has tended to lead to ahistorical interpretations of biblical texts. On the other hand, studies of the cultural environments of production of the biblical texts often neglect the fact that culture plays an equally important role in the reception of these texts.

It is exactly this exclusivity in approaches that prompted my own interest in intercultural biblical hermeneutics. ${ }^{5}$ A short description of its development is provided in the next section.

\section{The Development of Intercultural Biblical Hermeneutics}

The initial development of this field during the 1990s was not interested at all in intercultural hermeneutics in the reception-sense of the word. The observation at that stage was that many reception-oriented approaches developed during the latter half of the $20^{\text {th }}$ century, but no methods had been developed simultaneously to describe and analyse these processes of reception (De Wit 2004:477-492; De Wit 2008). Although biblical scholarship has developed a whole array of historical methods from the beginning of the $19^{\text {th }}$ century to describe the production of biblical texts in their ancient contexts, a similar development was still lacking on the reception side of biblical scholarship. During the 1990s, some attempts were therefore made to develop (qualitative) empirical methods for describing the reception of the Bible in contemporary contexts. The aim of these empirical hermeneutical methods was to establish the unique dynamics of interpretation processes to determine which factors contributed to the unique interpretations, and to suggest ways (mainly from historical scholarship) in which these biblical interpretation processes could be enriched and made more "adequate." At this stage, there was a clear normative aim in our research endeavours: as biblical scholars, we strove to increase the quality of biblical interpretations towards the norms set by historical and literary scholarship (see Jonker 2015a).

An observation that was made during these empirical investigations was that biblical interpretation often (if not always) takes place in a multicultural environment. The cultural influence on interpretation is never unilinear but always takes place within a network of cultural influences and configurations. This becomes even more acute when different individuals interpret biblical texts collectively, such as in church environments, bible study groups, etc. Each individual in the collective environment brings a unique cultural configuration into the process. Therefore, some theorists have indicated that 
collective interpretation results in a move away from a bipolar understanding of hermeneutics (i.e., an individual interpreter engaging with a biblical text on his/her own) to a multipolar understanding in which the complexity of cultural influences is acknowledged and included in our theories (Kessler 2004:452-459). We realised in the process that normative ideals are simply unrealistic in these academic endeavours. The role of the biblical scholar is rather descriptive, that is, the scientific skills from biblical scholarship are utilised to articulate and describe the dynamics in collective biblical interpretation processes.

One unfortunate point in the development of multipolar understandings of biblical hermeneutics is that the cultural difference between the contexts of origin of the biblical texts was gradually pushed into the background. The focus in these understandings is very strongly on the reception side of biblical interpretation, that is, how different cultural configurations influence collective interpretation processes. In my own work, I have therefore started criticising the exclusive focus on the reception side, with the effect that the cultural configurations that brought about the texts, and their determinative influence on the contemporary interpretation processes, are often neglected in our theoretical reflections (Jonker 2004:315-333; Jonker 2015b:239-256).

A further important point is the realisation that collective interpretation, or individual interpretation taking place within a network of cultural influences, challenges our understanding of the mode through which culture impacts our understanding. It emerged that a multicultural mode is simply insufficient. That is, acceptance of different cultural values alongside one another often leads to the complication or even breakdown of biblical interpretation processes into a multitude of meanings that compete with one another. Some theorists indicate that the inclusion of multiculturality in our interpretation processes simply leads to relativism, where no interpretation can claim any greater truth value than another. The challenge in multicultural situations; including the multiculturality created by the fact that the biblical texts stem from ancient, often unknown cultural backgrounds; is to develop intercultural modes of engagement with one another that lead to development of interpretations on all sides (Jonker 2006:19-28). In this respect, the idealist view of Habermas on complementary learning processes comes to mind again. The pertinent question in this hermeneutical development in biblical scholarship is therefore "how could we move from multicultural interpretations to intercultural modes of engagement?" The next section introduces the category of transformation into this theoretical reflection.

\section{Interculturality and Transformation}

Multicultural and intercultural hermeneutical approaches deliver different results. Whereas multicultural approaches lead to the construction of parallel, even oppositional meanings, intercultural approaches lead to transformation. This was witnessed time and again in the intercultural reading exercises that were organised and documented in an international project on intercultural biblical hermeneutics (De Wit et. al. 2004).

The method was fairly simple (De Wit 2004:3-53): In the first phase, participant groups from one cultural environment had to read a section from the Bible (all groups read the same text), and they had to interpret it with the strategies that they always used for biblical interpretation. This phase also incorporated a reflection on the characteristics of their interpretation strategies and interpretations. In the second phase, groups were 
linked to other groups that had an entirely different cultural composition. They were then requested to expose themselves to the reading strategies, interpretations, and reflections of their partner groups. Part of this phase was then to formulate responses to the partner groups' interpretations of the same biblical text. A third phase then gave groups the opportunity to consider feedback from their partner groups. Although there was no personal contact apart from audio and video recordings of the other group, it was observed that this interchange led to some transformation. The following categories that were taken from theoretical reflections on what constitutes successful intercultural communication (Kool 2004:360-376) were quite helpful when describing the kinds of transformation that were observed:

Attitude: Successful interaction requires a basic attitude of openness, trust, vulnerability, and willingness to criticize oneself and to see one's own faith insights as relative. This attitude applies to the reading process of the group itself as well as to the interaction with the partner group. Confrontation is allowed, but it must be based on trust. Not every type of motivation is productive. Motivation especially focused on acquiring new knowledge, focused on challenges, turns out to be enriching ....

Knowledge: The group needs basic knowledge of how cultures operate. Differences between groups soon become apparent, but it requires knowledge to see how these cultural differences can be identified and understood ....

Insight: Insight into the group's own reading attitude and interpretation method is also important. This insight enables participants to discover the connection between the method and the results of their interpretation and that of the partner group ... (De Wit et. al. 2004:506-507)

Interculturality thus rests on self-insight, on a certain amount of knowledge about the other, and on an attitude of reciprocity. From this understanding, it is apparent that interculturality can hardly be achieved in societies that are closed and restricted. On the other hand, it seems that interculturality can flourish in secular, and particularly postsecular, societies. We therefore turn now to the question that was asked in the introduction, namely "can intercultural biblical hermeneutics be of any value in postsecular contexts which are characterised by cultural and religious diversity?"

\section{The Bible in (Post-)Secular Contexts?}

At this point, I would like to turn to Habermas once again. Habermas makes a terminological distinction between "secular" and "secularist":

Unlike the indifferent stance of a secular or unbelieving person, who relates agnostically to religious validity claims, secularists tend to adopt a polemical stance toward religious doctrines that maintain a public influence despite the fact that their claims cannot be scientifically justified. Today, secularism is often based on 'hard' naturalism, i.e., one based on scientistic assumptions. ... [W] hat interests me in the present context is the question of whether a secularist devaluation of religion, if it were one day to be shared by the vast majority of secular citizens, is at all compatible with that post-secular balance between shared citizenship and cultural 
difference .... This question touches on deeper roots of the present unease than the 'multiculturalist drama.' (Habermas 2008:27)

Habermas then continues to indicate what would be necessary to foster this delicate balance between shared citizenship and cultural difference:

It is to the credit of the secularist that they, too, insist on the indispensability of including all citizens as equals in civil society. Because a democratic order cannot simply be imposed on its authors, the constitutional state confronts its citizens with the demanding expectations of an ethics of citizenship that reaches beyond mere obedience to the law. Religious citizens and communities must not only superficially adjust to the constitutional order. They are expected to appropriate the secular legitimation of constitutional principles under the premises of their own faith. ... But a change of mentality cannot be prescribed, nor can it be politically manipulated or pushed through by law; it is at best the result of a learning process (Habermas 2008:27-28).

This learning process is, however, according to Habermas, not something which is supposed to happen only on the side of religious communities. He indicates as follows:

But, shouldn't we turn the question around? Is a learning process only necessary on the side of religious traditionalism and not on that of secularism too? Do the selfsame normative expectations that rule an inclusive civil society not prohibit a secularistic devaluation of religion just as they prohibit, for example, the religious rejection of equal rights for men and women? A complementary learning process is certainly necessary on the secular side unless we confuse the neutrality of a secular state in view of competing religious worldviews with the purging of the political public sphere of all religious contributions (Habermas 2008:28).

If these views of Habermas are accepted, ${ }^{6}$ it seems that intercultural biblical hermeneutics can indeed be of assistance as practical means of fostering a complementary learning process. My own empirical research in the South African context took the inclusion of the Bible in this process for granted. ${ }^{7}$ In that context, the Bible is one of the greatest commonalities in a majority Christian society which is fragmented into a myriad of cultural, racial, language and political groupings. I argued there that this common resource that cuts across all divides in society should be embraced in order to foster a mentality of interculturality (Jonker 2006). However, in minority Christian contexts, the argument should be different. The use of the Bible to foster interculturality would not be self-evident in a local Lithuanian context or in other secular societies. One could also use any other text for that matter. However, I would like to argue that the Bible was and still is acknowledged in the majority of Western societies as a resource of cultural formation, whether it is for religious or for secular purposes (See

One should, of course, bring the points of caution highlighted by Dhillon (2010:139-156) into our discussions.

7 See e.g. Jonker (2015b). See also the reflections on African and European readings of the Bible in interaction with one another in De Wit and West (eds.) (2008). 
for example the arguments of Žižek 2008). It is furthermore acknowledged that the Bible is a resource for value formation, for better or for worse, in many societies. This point will be taken further in the conclusion below.

The fact that the Bible has gained authority over many centuries and has persisted as a point of orientation for many Western societies holds the benefit of a longitudinal and diachronic perspective. That is, the Bible does not simply foster intercultural exchange between contemporary Christian and contemporary secular individuals and groups. The Bible embodies the evolvement and development of religious and cultural communities over millennia, from early patriarchal religion and nomadic culture to early postexilic Judaism in the Persian era, to early Christianity during the Roman period. The Bible is not simply a static set of values but rather a dynamic illustration of the re-interpretation and re-appropriation of cultural and religious values in changed and changing sociopolitical and socio-religious circumstances. The Bible is, so to speak, the product of intercultural exchange over many centuries (Jonker 2011).

Admittedly, the authoritative scriptures of other religious traditions, such as the Qur'an of Islam, can also fulfil this function. However, the trajectories of hermeneutical developments in terms of the reading and interpretation of the Qur'an are different than those that relate to the Hebrew Bible and Christian scriptures. Only a minority of Qur'an scholarship holds to such a dynamic understanding of the hermeneutical processes underlying these scriptures. This is the reason why Habermas also remarks the following:

Religious citizens and communities must not only superficially adjust to the constitutional order. They are expected to appropriate the secular legitimation of constitutional principles under the premises of their own faith. It is a well-known fact that the Catholic Church first pinned its colors to the mast of liberalism and democracy with the Second Vaticanum in 1965. And in Germany, the Protestant churches did not act differently. Many Muslim communities still have this painful learning process before them. Certainly, the insight is growing in the Islamic world that today an historical-hermeneutic approach to the Koran's doctrine is required. But the discussion on a desired Euro-Islam makes us once more aware of the fact that it is the religious communities that will themselves decide whether they can recognize in a reformed faith their 'true faith.' (Habermas 2008:27-28)

My argument for using the Bible in intercultural-hermeneutic exercises for the fostering of interculturality in secular and post-secular contexts is therefore not primarily based on the fact that I am a Christian myself, and on top of that also a Hebrew Bible scholar. It is rather based on the conviction that the Bible - through its historical development and cultural appeal - has great potential to be a resource in societies that are in need of complementary learning processes, to use Habermas's term again.

\section{Conclusion}

I started my contribution with a reference to the crossing of boundaries in our time. Although some politicians, particularly in Western Europe and in the United States, see the recent movements in different parts of the world as something totally new and therefore as a challenge to nation states and closed cultures, the Bible is a witness that these movements are nothing new; in fact, they have occurred over millennia. The Bible 
is furthermore a witness to the importance of crossing boundaries in order to gain understanding of the Other. Intercultural biblical hermeneutics as a recent development in biblical scholarship has highlighted this aspect of these scriptures. In societies in need of crossing boundaries to gain understanding of the Other, this hermeneutical outlook on the Bible may just be of immense value.

Does this also apply to Eastern European contexts? My limited experience of Eastern European societies cautions me not to make overly bold statements or be too prescriptive. This limited exposure to Eastern European contexts, in combination with my discussion of Habermas's use of the concepts of 'post-secular' and 'secularism', leads me to at least hypothesise the following: In the post-secular (or even post-secularist) societies of Eastern Europe, where interaction with Western societies is now the order of the day and where immigration also belongs to present realities, intercultural biblical hermeneutics could potentially serve as a powerful vehicle to foster the complementary learning process (a la Habermas) that would be necessary for Eastern European societies to flourish. This does not mean that the Bible should necessarily be studied from a religious perspective or for the purpose of converting anyone to a specific religious position. However, the Bible, as cultural product that grew over many centuries, embodies the dynamics of "crossing boundaries" - not only culturally, but also temporally. The Bible should be studied in order to obtain a deeper understanding of how repositioning in changed and ever-changing socio-cultural circumstances could take place without severing ties with past. Although intercultural biblical hermeneutics is a particularly helpful approach to studying the vitality of the religious traditions of the past and their adaptability to new contexts, it could also serve the same purpose in post-secular (or post-secularist) societies.

\section{BIBLIOGRAPHY}

Casanova, J. 2012. Are we still secular? Explorations on the secular and the postsecular. in Nynäs, P., Lassander M., and Utriainen, T. (eds.), Post-secular society. London: Routledge, 27-46.

Cezula, N.S. 2013. Identity formation and community solidarity: Second Temple historiographies in discourse with (South) African theologies of reconstruction. Thesis: Stellenbosch University. http://scholar.sun.ac.za/handle/10019.1/80038.

Critchley, S. 2012. The faith of the faithless: Experiments in political theology. London: Verso Books.

De Wit, J.H. 2004. Intercultural Bible reading and hermeneutics. in De Wit, J.H., Jonker, L.C., Kool, M., and Schipani, D.S. (eds.), Through the eyes of another: Intercultural reading of the Bible. Elkhart: Institute of Mennonite Studies, 47792.

. 2008. "My God", she said, "Ships make me so crazy." Reflections on empirical hermeneutics, interculturality, and Holy Scripture. Trans. H. Jansen. Amsterdam: VU University.

2004. Through the eyes of another: Objectives and backgrounds. in De Wit, J.H., Jonker, L.C., Kool, M., and Schipani, D.S. (eds.), Through the eyes of another: Intercultural reading of the Bible. Elkhart: Institute of Mennonite Studies, 3-53. 
De Wit, J.H, Jonker, L.C., Marleen Kool, and Schipani, D.S. (eds.) 2004. Through the eyes of another: Intercultural reading of the Bible. Elkhart: Institute of Mennonite Studies, 2004.

De Wit, J.H. and West, G.O. (eds.) 2008. African and European readers of the Bible in dialogue: In quest of a shared meaning. Leiden: Brill.

Dillon, Michele. 2010. Can post-secular society tolerate religious differences? Sociology of Religion 71(2): 139-156.

Gertz, J.C., Berlejung, A., Schmid, K., and Witte, M. 2012. T\&T Clark handbook of the Old Testament: An introduction to the literature, religion and history of the Old Testament. 1 st ed. London: T \& T Clark International. https://www.logos.com/product/33099/tt-clark-topics-in-old-testament-studies. Giffone, B.D. 2016. "Sit at my right hand": The chronicler's portrait of the tribe of Benjamin in the social context of Yehud. LHBOTS 628. London: Bloomsbury Publishing.

Habermas, J. 2008. Notes on post-secular society, New Perspectives Quarterly 25(4): $17-29$.

Jonker, L.C. 1996. Exclusivity and variety: Perspectives on multidimensional exegesis. Contributions to biblical exegesis and theology. Kampen: Kok Pharos.

- 2004. Jesus among the ancestors: Continuity and discontinuity. in De Wit, J.H., Jonker, L.C., Kool, M., and Schipani, D.S. (eds.) Through the eyes of another: Intercultural reading of the Bible. Elkhart: Institute of Mennonite Studies, 315-333.

- 2006. From multiculturality to interculturality: Can intercultural biblical hermeneutics be of any assistance? Scriptura 91: 19-28.

- 2011. 'Lewend en Kragtig'? Die Hermeneutiese Dinamika en Implikasies van (Her)Interpretasie in die Ou Testament, Nederduitse Gereformeerde Teologiese Tydskrif 52(1). Available from: http://ngtt.journals.ac.za/pub/article/view/12.

. 2013. Why history matters: The place of historical consciousness in a multidimensional approach towards biblical interpretation, Verbum et Ecclesia 34(2): Art. \#775.

- 2015a. From adequate biblical interpretation to transformative intercultural hermeneutics: Chronicling a personal journey. Intercultural biblical hermeneutics series 3. Elkhart: Institute of Mennonite Studies, . 2015b. Of writers and readers: Facilitating the intercultural encounter between (ancient) texts and (contemporary) readers. in Schipani, D.S., Brinkman, M., and Snoek, H. (eds.), New perspectives on intercultural Bible reading: Hermeneutical explorations in honor of Hans de Wit. Elkhart/Amsterdam: Institute of Mennonite Studies/Vrije Universiteit Amsterdam, 239-256.

- 2016. Defining all-Israel in Chronicles: Multi-levelled identity negotiation in late Persian Period Yehud. Forschungen zum Alten Testament I 106. Tübingen: Mohr Siebeck.

Jonker, L.C., and Lawrie, D.G. 2005. Fishing for Jonah (anew): Various approaches to biblical interpretation. Stellenbosch: African Sun Media.

Kessler, Rainer. 2004. From bipolar to multipolar understanding: Hermeneutical consequences of intercultural Bible reading. in De Wit, J.H., Jonker, L.C., Kool, 
M., and Schipani, D.S. (eds.), Through the eyes of another: Intercultural reading of the Bible. Elkhart: Institute of Mennonite Studies, 452-459.

Kool, M. 2004. Intercultural Bible reading as a practical setting for intercultural communication. in De Wit, J.H., Jonker, L.C., Kool, M., and Schipani, D.S. (eds.), Through the eyes of another: Intercultural reading of the Bible. Elkhart: Institute of Mennonite Studies, 360-376.

Lipschits, O., Knoppers, G.N., and Oeming, M. (eds.). 2011. Judah and the Judeans in the Achaemenid Period: Negotiating identity in an international context. Winona Lake: Eisenbrauns.

Schmid, K. 2014. Literaturgeschichte des Alten Testaments: Eine Einführung.

Studienausg., 2. durchges. und bibliograph. erw. Aufl. Einführungen. Darmstadt: Wissenschaftliche Buchgesellschaft.

Taylor, C. 2007. A secular age. Boston: Harvard University Press.

Žižek, S. 2008. The fragile absolute, or, why is the Christian legacy worth fighting for? London: Verso. 